\title{
Realism and politics in alienated space: Trevor Griffiths's plays of the 1970s in the television studio
}

Article

Published Version

Panos, L. (2010) Realism and politics in alienated space: Trevor Griffiths's plays of the 1970s in the television studio. New Theatre Quarterly, 26 (3). pp. 273-286. ISSN 0266-464X doi: https://doi.org/10.1017/S0266464X10000461 Available at https://centaur.reading.ac.uk/17760/

It is advisable to refer to the publisher's version if you intend to cite from the work. See Guidance on citing.

To link to this article DOI: http://dx.doi.org/10.1017/S0266464X10000461

Publisher: Cambridge University Press

All outputs in CentAUR are protected by Intellectual Property Rights law, including copyright law. Copyright and IPR is retained by the creators or other copyright holders. Terms and conditions for use of this material are defined in the End User Agreement.

www.reading.ac.uk/centaur 
Central Archive at the University of Reading

Reading's research outputs online 


\section{New Theatre Quarterly}

http://journals.cambridge.org/NTQ

Additional services for New Theatre Quarterly:

Email alerts: $\underline{\text { Click here }}$

Subscriptions: Click here

Commercial reprints: Click here

Terms of use : $\underline{\text { Click here }}$

\section{Realism and Politics in Alienated Space: Trevor Griffiths's Plays of the 1970s in the Television Studio}

Leah Panos

New Theatre Quarterly / Volume 26 / Issue 03 / August 2010, pp 273 - 286

DOI: 10.1017/S0266464X10000461, Published online: 11 August 2010

Link to this article: http://journals.cambridge.org/abstract_S0266464X10000461

How to cite this article:

Leah Panos (2010). Realism and Politics in Alienated Space: Trevor Griffiths's Plays of the 1970s in the Television Studio. New Theatre Quarterly, 26, pp 273-286 doi:10.1017/S0266464X10000461

Request Permissions : $\underline{\text { Click here }}$ 


\section{Leah Panos}

\section{Realism and Politics in Alienated Space: Trevor Griffiths's Plays of the 1970 in the Television Studio}

The television studio play is often perceived as a somewhat compromised, problematic mode in which spatial and technological constraints inhibit the signifying and aesthetic capacity of dramatic texts. Leah Panos examines the function of the studio in the 1970s television dramas of socialist playwright Trevor Griffiths, and argues that the established verbal and visual conventions of the studio play, in its confined and 'alienated' space, connect with and reinforce various aspects of Griffiths's particular approach and agenda. As well as suggesting ways in which the idealist, theoretical focus of the intellectual New Left is reflexively replicated within the studio, Panos explores how the 'intimate' visual language of the television studio allows Griffiths to create a 'humanized' Marxist discourse through which he examines dialectically his dramatic characters' experiences, ideas, morality, and political objectives. Leah Panos recently completed her doctoral thesis, 'Dramatizing New Left Contradictions: Television Texts of Ken Loach, Jim Allen, and Trevor Griffiths', at the University of Reading and is now a Postdoctoral Researcher on the AHRC funded project, 'Spaces of Television: Production, Site and Style', which runs from July 2010 to March 2014.

TREVOR GRIFFITHS gained critical acclaim during the 1970 for plays which often dealt with issues and dilemmas facing the Left and the question of how to be a socialist. This article explores how Griffiths's use of the television studio produces a particular kind of exploration of the socialist subject, facilitating his investigations into the relationship between the personal and the ideological. Furthermore, it develops wider questions about how the studio functions in Griffiths's work, examining how its qualities of alienation, construction or 'constructedness', and intimacy operate dynamically in his television texts.

These issues are addressed by focusing on three plays by Griffiths, all produced for television in 1974: All Good Men (Play for Today, BBC1, 31 January 1974); Absolute Beginners (Fall of Eagles series, BBC1, 19 April 1974); and Occupations (Granada TV, 1 September 1974). I want to explore how the studio space, discursive form, and shooting strategies interact in specific instances with Griffiths's texts to reinforce meaning.
Although his first performed plays were produced in the theatre, Griffiths had longstanding links with television, having written several unrealized scripts for television during the 1960s, and having worked as a Further Education Officer for the BBC. Like many playwrights of his generation, it was only after he made his name in the theatre that Griffiths went on to have television plays produced, and several of his theatre works were also later seen on television. However, even his theatre 'break' was indirectly enabled by television, since his first big 'hit', Occupations (performed in 1970), was 'produced at a fringe theatre subsidized by Granada Television as a means of recruiting writers for its expanding drama department ${ }^{\prime}{ }^{1}$

During the 1970s Griffiths repeatedly stressed his preference for working in television, maintaining that he mainly continued to work in theatre for the increased leverage it gave him in television. ${ }^{2}$ For a writer with an explicit political message, television was important as a medium that could reach a large national audience. ${ }^{3}$ It also had greater 
cross-class appeal compared to the theatre, which he still perceived as a bourgeois cultural sphere. Griffiths agreed with the notion that the regular television play was 'the nation's theatre', remarking that 'there are fewer cinemagoers in Britain now than there are anglers; fewer regular theatregoers than car-rallyers. For most people, plays are television plays, "drama" is television drama. ${ }^{4}$

\section{'The Quality of Listening'}

Contrary to the common association of the so-called 'golden age' of the television play with a few well-known all-film dramas, ${ }^{5}$ throughout the 1970 s the television studio remained the predominant site for television drama. For various technological and cultural reasons, theatre had exerted a strong influence over television drama's forms and practices, as well as audience expectations of the medium, and although this began to be challenged in the mid-196os with technological advances and institutional shifts, theatrical forms of drama remained prevalent. The acceptance that words, rather than visual form, were where television drama's meanings really lay was one sense in which television drama retained connections to both theatre and radio, and the writer rather than the director was considered the 'author' of a television work.

This accepted emphasis on word over image was undoubtedly important in influencing the kinds of plays that Griffiths wrote in the 1970s, enabling him to organize them around highly structured, lengthy political conversations and analyses of ideas. In his debut single play for television, All Good Men, an aged Labour MP, Edward Waite, is engaged in intense political discussion about the failure of social democracy by his Trotskyite son, William, during birthday celebrations at the family home.

Absolute Beginners, which was commissioned as one episode of a thirteen-part BBC historical drama series, Fall of Eagles, deals with political manoeuvrings around the 1903 Second Congress in which Lenin moved to restrict membership of the Russian Social Democratic Labour Party, which would even- tually become the Communist Party, exploring the often disturbing implications and consequences of Lenin's vanguardism.

Occupations, Griffiths first full-length play for the stage, had its premiere at the Stables Theatre, Manchester, in 1970. Subsequently adapted for television, it explores the philosophical and tactical differences between Christo Kabak, a Bulgarian member of the Communist International, and Antonio Gramsci, leading Italian Marxist intellectual, during the 1920 Fiat factory occupations in Turin, comparing the characters' respective jaded pragmatism and humanist idealism via their conversations and interactions in Kabak's hotel room.

All three of these plays deal extensively with political issues, and the historical dramas have a particular complexity, since their subject matter is further removed from the viewer's frame of reference than All Good Men, which refers to recent British politics, although it also makes challenging ideological points.

While 'scripted' dialogue was expected in studio plays, Griffiths's excessive reliance on words has been noted, perhaps partially as a result of the breaking down of theatrical conventions that was taking place during this period, but also because of the intensely discursive political ideas being dramatized. ${ }^{6}$ Griffiths himself later remarked, 'A lot of my early plays are about hearing; they're actually about the quality of listening in the theatre,' and he goes on to contrast this with his later emphasis on 'looking and the quality of seeing'. ${ }^{7}$ The verbal emphasis also suggests that these plays have an affinity with radio as much as with theatre, and although there are advantages in making them as television plays they are not specifically televisual pieces.

Griffiths has, at moments, expressed reservations about the prevalence of rhetoric in his early works. He revealed in an interview with John Wyver that he believed he had made 'a significant technical and formal advance' with his all filmed, less exclusively dialogue-led drama, Country: a Tory Story (Play for Today, BBC1, 20 October 1981). It was 'a move away from the lengthy, articu- 
lated ratiocination which is one way, a rather dumb way, of characterizing my earlier plays' ${ }^{8}$ Here he seems somewhat ambivalent about these works' wordiness, simultaneously defending and criticizing his excessive verbalization of political ideas as a fictional mode at that time.

It is no accident that Griffiths developed a more significant visual dimension in his writing through working exclusively with film in the all-film Country, and and in four cinema screenplays written during the 1980s. ${ }^{9}$ However, the verbal discussion that the early works foreground enables a very direct relationship between dramatic and political debate to be established, utilizing the capacity for analysis that this affords. These plays are also more suited to the demands of recorded television studio drama, with its limited space and de-prioritizing of mise-en-scène due to the aesthetic limitations of the environment.

There is a large element of highly scripted and polished dialogue in Griffiths's plays of the 1970s, and while such 'literate' speech was an aspect of many television authors' works, it is significant that Griffiths wrote in this way during a period in which television practitioners making work on and about the Left tended to favour 'filmed drama where realism involved a drive towards social extension'. ${ }^{10}$ The studio mode undoubtedly promoted the prioritizing of ideas expounded through dialogue over matters of representational authenticity, the latter being of such fundamental concern to film-makers such as Ken Loach and Tony Garnett, motivating their pioneering work outside the studio.

\section{Empirical and Idealist Approaches}

The differences between Ken Loach's and Griffiths's methods and concerns echo a wider division within the New Left at the time between empirical and idealist approaches, which cohered around a dichotomy of experience and theory. Raymond Williams clarifies the 'general modern use' of empiricism as concerned with 'the broad distinction between knowledge which is based on observation (experience and experiment) and knowledge which is based on the conscious application of directing principles and ideas, arrived at or controlled by reasoning' ${ }^{11}$

This encapsulates the different imperatives informing respectively the filmed documentary drama and the theatrical recorded television studio modes of Loach and Griffiths during the 1960s and 70s. The former strives to represent itself as making socio-political arguments through the observation of real environments and people, while the latter makes a case through presenting a consciously and obviously constructed set of ideas in a controlled environment.

The empirical-idealist distinction also informs the sense of whose account is being heard in the drama, and how far dialogue is 'authored'. The methods of documentary drama encourage the illusion of the image and dialogue as unmediated, and Loach has spoken of one of his main motivations as being to 'give a voice to those who are often denied it'; 12 but it is Griffiths's own 'voice' that comes through strongly in his plays of this period, through the educated radicals who populate his plays, and through the recurrent casting of Jack Shepherd in roles which voice the writer's own concerns. ${ }^{13}$

'Empiricism' was to become a term of abuse for critics influenced by structuralist ideas, who argued that a focus on observing the experience of the subject is insufficient and that further theoretical analysis is required in order to understand the structure of society, institutions, and the subject. Griffiths's use of radical intellectuals conducting theoretical and historical discussions allows his dramas of this period to transcend the level of political and structural analysis in other dramas concerned with socially extending representations.

The distinction between empirical and idealist forms of enquiry also overlapped with older socialist traditions of what Andrew Milner has termed 'class-based' and 'ruling ideas' Marxism. Milner says the central question was 'whether or not socialist consciousness could develop spontaneously out of working-class life experience, especially that of industrial conflict', or whether 'workers had to be led to socialism through 
the politico-ideological interventions of a socialist political party ${ }^{\prime}{ }^{14}$

As Milner explains, the latter position was reinforced by the 1902 publication of Lenin's pamphlet What is to be Done?, which argued for the role of the revolutionary vanguard party, and it is significant that the role of a political party is an issue that Griffiths's work repeatedly addresses. For example, Absolute Beginners deals with the events and issues surrounding Lenin's attempt to refine the nature and role of the party and consolidate his leadership, while Occupations is also concerned with the power held by the vanguard and the responsibilities that this entails. ${ }^{15}$ Griffiths's own role within the contemporary political vanguard of the New Left is also worth noting, since his texts demonstrate a concern with educating the audience about historical-political events, and with providing an analytical locus of ideas for the Left.

The theatrical mode of these works prompts the question of how far they adhere to bourgeois concepts of cultural 'value' as 'well-made' plays. They are, in a sense, related to the 'drawing-room' plays to which much post-1956 theatre opposed itself, with their focus on middle-class characters and intellectual dilemmas, their use of educated, literate language rather than the demotic, of southern rather than northern accents, and often the casting of actors with a theatre pedigree, such as Patrick Stewart (who joined the Royal Shakespeare Company in 1966) as Lenin, and Donald Pleasence as Kabak. ${ }^{16}$ However, the middle-class connotations of the dramatic form are offset by the overtly Marxist analyses and dilemmas which are the play's content.

\section{Alienation and Socialism}

The fact that long discursive socialist dialogues were occupying prime-time television suggests that Griffiths was employing the theatrical mode in order to subvert it from within, and to enable his interventions in the mainstream. Indeed, Griffiths has described his pursuit of an agenda of 'strategic penetrations', which he describes as, 'a phrase I use a lot about the socialists and Marxists in bourgeois cultures' ${ }^{17}$

In their article, 'Who Framed Theatre? The "Moment of Change" in British TV Drama', Madeleine MacMurraugh-Kavanagh and Stephen Lacey point to how the studio environment provided greater opportunities for 'dramatic "licence"' than filmed drama, which

spoke a different 'language', an idiom that resisted metaphor and environmental innovation in its adherence to surface realism [and excluded] a range of alternative experiences and representations for which it was too 'big', too 'social', and too externalized. ${ }^{18}$

They make a case for the television studio as a space that was conducive to exploring ideas through non-naturalistic visual and verbal forms, as

already essentially 'unreal' in terms of the verisimilar [it] allowed for freedoms within language, image, and metaphor that seemed to be denied to film. ${ }^{19}$

Indeed, there is a sense that the studio as an 'alienated' space removed from society enabled such theoretical material to be realized, suspended away from the material world; and by this logic Griffiths's political discussions and scenarios are under less pressure to offer experiences that relate directly to the outside world. As well as deriving from the hermetically sealed physical space of the studio, Griffiths's texts also demonstrate the wider sense of the television single play as a 'space for ideas' within television schedules, a conceptually exploratory area that exists outside television's continuous everyday flow.

However, the solipsism of the studio also has potentially negative connotations. On one level the remove which the studio implies can be interpreted as a reflection of ideological alienation, as if the marginalization and lack of general social currency of socialist discussion is demonstrated by this dramatic distance from the outside world. It also suggests a failure to engage directly with contemporary society; indeed, Loach and 
Garnett's move outside the studio confines was motivated by precisely their perception of the need to reconnect with society and experience material reality.

This point seems to be crucially connected to the sort of political intervention that Griffiths makes, since Occupations, Absolute Beginners, and All Good Men are not about society so much as socialist tactics and belief systems. The theoretical discussions, particularly in Occupations and Absolute Beginners, relate to specific historical problems that, while relevant to the Left's theoretical position, are detached from contemporary instances of militancy, echoing the wider phenomenon within the New Left in the 1970s of an increasing gap between intellectual and proletarian factions.

\section{A Deficit of Experience}

This also highlights how the middle-class radicals' surplus of theory existed in relation to a deficit of experience of militancy on their part. Although the theoretical discursive form of his plays suggests Griffiths's position is within the camp of ideas rather than experience, the problematic issue of the relationship between theory and practice is a subject explored in them. For example, in All Good Men, the young Trotskyite William is criticized by his father, Edward Waite, for his lack of experience, to which William responds by highlighting his father's ideological and imaginative bankruptcy:

WAITE: It's all so easy, isn't it? You sit there behind your little desk in your little room in your little ivory tower and you read your Marx and your Trotsky and you get your slide rule out and do a couple of simple calculations and you have your blueprint. Revolution.

Total change. Overnight. Bang. Especially bang. You have to have your bit of theatre as well, don't you? Reality isn't like that. ... We live in the same world. It doesn't change because we shut our eyes and dream.

WILLIAM: It doesn't change unless we shut our eyes and dream.'I take my desires for reality, because I believe in the reality of my desires. ${ }^{20}$

As with many of his works during this period, Griffiths establishes a dialectic bet- ween these two characters' stances, recognizing the limitations of both approaches and implying that a synthesis is necessary.

The sense of the studio as an 'alienated' and 'abstracted' space connects with the detachment of the various characters' from the outside world in several of Griffiths's plays of this period. Edward Waite's class alienation is depicted in All Good Men and political, personal, and ideological alienation is dealt with in Occupations and Absolute Beginners. In All Good Men it is suggested that the Labour MP Edward Waite, soon to be made a peer, has lost touch with his workingclass roots and lives at a remove from the people that he should be representing. The play draws attention to the disparity between Waite's extolled Labour principles and his own comfortable life-style in a large country property.

Massingham, the upper-class television producer who visits Waite, is surprised by the affluent surroundings, remarking, 'It's a lovely house. I wouldn't have thought Surrey . . . right, somehow, given your life.' Later, William criticizes his father for moving out of his own working-class constituency to a middle-class area: 'Four bedrooms, attics, cellars, gardens, playschools, parks. . . . Not the sort of house you'd find in Beswick now, was it? Because Beswick was single-class housing. Working class. ${ }^{21}$

Earlier in the play, in preparation for a television interview that Massingham will conduct, Waite tells him some facts about his early life as one of six children in a family living in dire poverty in Manchester, adding how, in spite of their terrible circumstances:

We had each other. Down the street, up the street, round the corner, down the next one. We were all in the same boat. Bound to each other, you might say. Aunts and uncles and cousins and ... just neighbours. There mightn't have been much hope around, but there wasn't too much despair either. ${ }^{22}$

Waite's mention of the kind of intensely socialized conditions that he grew up in highlights his current isolated and private mode of life. The studio mode of representation fits the theme of Waite's withdrawal 
from the community and his geographical and political distance from 'the people'. Waite's allusion to the collective structure of working-class life, based around their close proximity and sense of a shared living space, highlights the middle-class interior of his present house and reflects on how the mode of the studio play is unable adequately to represent the life of a working-class community in the way that Loach and Garnett's filmed locations do. As MacMurraughKavanagh and Lacey note, 'film drama was seen to involve and reflect the "mass" in terms that studio drama could never effect (as a result of the necessary facts of imposed structure and environmental suspension from the world) $)^{23}$

Occupations and Absolute Beginners are both centred round characters who are living in some form of seclusion from the world around them, and the studio spaces within which they are shot enhance the sense of them living in a state of controlled suspension from social interaction. In Occupations, a Bulgarian Soviet agent, Kabak, is conducting covert business affairs and political meetings from a hotel room in Turin, admitting a range of invited guests into his suite until eventually a government official orders him to leave the country the following morning. Absolute Beginners is set during Lenin's period of exile in London, and the main setting is the boarding house in which he lives and works. When Trotsky arrives, he must give a coded message and a password to Lenin's wife Krupskaya before he is allowed entrance into the space, demonstrating the secrecy of Lenin's location and increasing the sense of it as an exclusive space.

As well as the notion that the secrecy of these characters' presence necessitates their existence in such spaces, there is a further sense that, aside from their enforced physical separation, they choose to remain aloof from others for reasons connected to their political sensibilities. The alienated space of Kabak's hotel room seems to reflect his own ideological alienation from the masses - a potential source of the crude instrumentalist view of the workers that he relates to Gramsci, and his emotional alienation from his dying mist- ress, whom he finally abandons. Lenin alienates himself from his close colleagues during the play, while making the difficult decision to expel certain factions from the Russian Social Democratic Labour Party, incurring the wrath and anger of the former comrades whom he has turned against for political reasons.

Later in the play, we learn that a comrade from the Soviet Union has arrived, seeking an audience with Lenin over his wife's suicide, which occurred after she was impregnated and slandered by their political associate, Agent Bauman. Lenin refuses, arguing that Bauman is an 'outstanding agent', and dismissing Martov's concern for the party's ethical consciousness as 'metaphysics', since 'just now we're trying to make the revolution possible'. The theme of closing off contact with others thus functions on more than one level, and the sealed space of the studio echoes the disconnection of these figures from the populace and their lack of wider accountability to the people whose interests they supposedly serve.

The few brief filmed inserts that feature in Absolute Beginners tend to add a symbolic rather than socially extended dimension of meaning. The location-filmed opening scene, set in Tsar Nicholas's light and spacious palace, as well as demonstrating his wealth provides a contrast to the shady, cramped world which the revolutionaries occupy. Later, Lenin and Martov chat as they walk past the British Museum, a symbol of imperialism and knowledge, and in the penultimate scene, in which the break between Lenin and his former colleagues is cemented, the group is gathered around Karl Marx's grave, emphasizing that this enforced tactical division between factions by Lenin is occurring in spite of the common source of their ideas from Marx himself.

\section{The Studio and Structured Ideas}

MacMurraugh-Kavanagh and Lacey argue that the obvious construction of the television studio play frees it from some of the constraints of verisimilitude, expanding the range of subjects that can be dealt with and 
the ways in which they can be addressed. I would develop this idea further in relation to Griffiths's work in two related ways: first, the manner in which they negotiate the boundary between being structured interventions while still retaining reflectionist aims; and second, related to this, the way that political analysis is achieved through realist characters, challenging the Brechtian notion that this is not possible.

Discussing David Mercer's play, Let's Murder Vivaldi (Wednesday Play, BBC1, 10 April 1968), MacMurraugh-Kavanagh and Lacey state that

a determinedly claustrophobic interiority resists the exterior world to such an extent that, in the midst of the drama, it proves difficult to imagine the characters existing within the various realms (offices, shops, etc.) to which they refer. ${ }^{24}$

While Griffiths's television texts are not consciously non-naturalistic in the way that Mercer's play is, the sense that a character's existence as 'fully rounded' often seems to be secondary to their function as agents of discussion, and they do not fulfil the liberalhumanist criterion for fictional characters to appear to 'have a life' off the page or screen, which is often employed in judging the adequacy of a character. ${ }^{25}$

This is true of much studio and theatre drama as a result of the constraints of the form, the remove from social spaces, and the necessity of delivering the play's themes through dialogue. However, as Griffiths's agents' discussions are more explicitly political than those in most plays, the very nature of the dialogue also pulls away more frequently from characters' particular lives and towards the realm of an 'impersonal' social dimension. For example, William's climactic discussion with his father in All Good Men, when he is held to account for his party's record in office, is partly an 'objective' assessment of the failures of the post-war Labour government, conducted in a rhetorical question-and-answer style, and partly an emotive familial conflict, based on William's rejection of his father's hypocrisy and his cosy personal existence detached from the working class.
In response to a comment about his work being 'firmly in the realist mode' Griffiths himself has noted, 'there's something about a speech that lasts for twenty minutes . . that changes the nature of what's happening'. ${ }^{26}$ Although he remained committed to realism (rather than non-naturalistic form), here he shows an awareness of how his dramatic dialogue stretches verisimilitude. There is also a greater reliance on dialogue to fill in social and class dimensions which the studio situation cannot provide and, with the expectation of more foregrounded dialogue, an increased opportunity for directly verbalizing issues that are normally implied in a more action-based mode.

For example, in All Good Men Griffiths develops the theme of class conditioning by continually foregrounding characters' class dimensions within their own observations about each other, providing a sort of social structural commentary woven into the play. It is not just the Trotskyist William who is a conduit for these ideas, for Waite's daughter Maria, a secondary-school art teacher with no clear political agenda, also delivers a scathing critique of the class background of the television producer Massingham:

MARIA: Too bright for Eton. Marlborough.

MASSINGHAM: Winchester.

MARIA (laughs): Yes. I should have recognized

that distinctive, 'I'm not important' style of arrogance.

MASSINGHAM (smirking): It's amazing. You're exactly the way I expected your father might be.

MARIA: Don't tell me, it's 'chip on the shoulder' time. You're all the bloody same. The moment your sleek charm fails to make the requisite impression, you fall to whining about chips on the shoulder. Your dispensation isn't natural, you know, or God-given. It's bred. Like my resistance. I'd have thought they'd have told you that when they were 'making' you. $^{27}$

Such discussions seem to test the extent of class discourse the scenario will comfortably permit, both within the scenario itself and for the audience as 'realistic' drama. The subject of the discussion makes Massingham uncomfortable, because he prefers to elide class differences, but William, as a passionate and 
angry young socialist, overrides the social etiquette that might have been expected within a middle-class family home.

Griffiths goes to some lengths to contain and contextualize William's speeches within the narrative scenario, reinforcing the limits of his dialogue's subversion of naturalism and demonstrating the line that he treads between a concern for the interpersonal narrative and wider ideas being communicated. William's antagonistic relationship with his father is established in an early conversation between Waite and his daughter Maria when she asks, 'Have you had a chat with William yet?' to which Waite replies, 'I've never had a chat with William in my life. You can have a fight with him, or a flaming good row, or you can try and make the occasional interruption to his speeches, but a chat with him?' ${ }^{28}$

Further references are made to 'speeches' throughout the drama - as, for example, when Massingham, anticipating an attack on his upper-class background from William, tells him, 'I believe I've already had the next speech from your sister. ${ }^{29}$ As well as contextualizing William's mode of address within the narrative, Griffiths is reflexively referring to the wordy mode he is using to deliver his own ideas via the character. While the play uses William as a conduit to deliver its critique of Labour policy, it poses his method of doing so (verbally attacking his sick, aged father) as problematic, and implicitly suggests that his insensitivity may be representative of a wider tendency among socialists to alienate others by putting politics before interpersonal concerns, an issue I explore further below. This points towards how the plays negotiate the boundary between the personal and the political.

\section{Socialist Subject and 'Intimate Screen'}

An idealist approach to socialism, informed by European theory as articulated in Griffiths's texts of this period, is often equated with the use of Brechtian, modernist, and nonnaturalistic modes, such as that adopted by French New Wave cinema, and particularly by the director Jean-Luc Godard. Godard consciously adopts devices that draw attention to the text's formal construction, rupture textual unity, and destroy the illusion of the unmediated image. Griffiths's work of the 1970 does not, in the main, experiment with such devices, but sustains a continuous, character-based narrative scenario. While Brecht polemicized against the conventions of realism, believing it was necessary to abstract from the viewpoint of individual characters in order to understand the world, Griffiths has sided with Brecht's opponent, Georg Lukács, in his belief that 'individuals had access, through their own personal experience, to the social whole', ${ }^{30}$ and concurring with 'that whole idea of character working as a confluence of important social and political and moral forces in society, in real historical time'. ${ }^{31}$

Although the Lukácsian model of realism offers the useful notion that characters can bridge the individual and social, the specific and the typical, Lukács's ideas about realism were formulated in relation to nineteenthcentury forms, and have limited application to a consideration of audio-visual dramatic form. Furthermore, it is arguably not strictly a Lukácsian model that Griffiths is adopting, since he relies heavily on particularly enlightened and politically aware characters, including Lenin and Gramsci, with insights beyond that of the 'typical' individual at each juncture of history that he deals with, seemingly supporting Brecht's view of the limitations of such characters in his use of strategies beyond the unified, Lukácsian 'intensive totality', in which social forces are dissolved into typical concrete phenomena.

In addition, since the question of how to be political and to locate the meeting point of personal qualities and political tactics are central questions in the plays, they contain a self-reflexive and potentially contradictory relationship between ideas and experience that Lukács's theory does not address, focusing instead on the personal and the historical as fully integrated elements instead of components of a dialectic which is itself the issue in question.

This dialectic of the individual and the socio-political is at the centre of both Occupations and Absolute Beginners, which explore 
the connections between humanist ethics and revolutionary tactics. While the plays' historical contexts are of direct relevance to the post-1968 period in which Griffiths is writing, the plays' most central concern is the relationship between morality and political necessity. Thus, in Occupations, Gramsci's humanist philosophy is counterposed with Kabak's cynical, instrumentalist opinion of the masses as a 'machine' with which to make revolution, and the play asks whether Gramsci's reluctance to risk harming the workers led to a lost opportunity for revolutionary action, as well as associating Kabak's cold, detached view with the capacity for atrocities such as later occurred under Stalin. Absolute Beginners explores Lenin's belief in the necessity to limit the Russian Social Democratic Labour Party in order to create an effective vanguard party, thereby putting political necessity before personal morality.

Griffiths explores the personal as well as the political level of socialist subjectivity by using realist characters, retaining the 'subject' as the site in which this is achieved. Dorrian Lambley has discussed the fact that Marxist drama has often failed to posit 'a coherent theory of subject' due to 'the assumption that the existence and functioning of the subject is subsumed by his/her position in the social discourse', and so neglecting 'to theorize the subject of desire within its ideological structure' ${ }^{32}$

Griffiths's dramas reassert the presence of a 'desiring' subject in Marxist drama by addressing socialist characters' personal relationships, decisions, and emotional anguish. In considering the place of individual morality and responsibility in political decisions, the plays clearly present questions related to socialist humanism, a key strand of New Left philosophy that was developed by E. P. Thompson, largely in response to Stalinism's dehumanized system, which 'reasserted the importance of ethical commitments for socialists', and proposed that socialism 'be reconstituted as the creation of individual human subjects'. 33

Griffiths's decision to work within a realist model, using narrative continuity and developing characters at the centre of the work rather than experimenting with alternative, more fragmented forms, seems to suit his concern to 'humanize' Marxism and constitute it as something other than an analytical structure of ideas, detached from personal concerns.

\section{The Interiorizing Process}

The scale of the television studio and the established visual language for shooting studio drama were also conducive to the relaying of big ideas within small interpersonal exchanges. Right from the birth of television up to the present, practitioners and critics have argued the benefits of television's language of medium and close-up shots for exploring character interiority, and have even maintained that this confinement, and the sense of intimacy that it encourages, is television's specific strength as a medium. For example, Dennis Potter maintained that

Television is equipped to have an interior language. Certainly one of the strands in TV drama is that of the interiorizing process, the concern with people's fantasies and feelings about the shape of their lives and about themselves. ${ }^{34}$

There are many grounds for challenging the essentialism of such a claim. ${ }^{35}$ But the established beliefs and dominant practices associated with the 'fetishization of the close-up style $^{\prime 36}$ and the 'intimacy' of 'a small-scale production, few characters, concerned with emotional drama rather than spectacle, ${ }^{37}$ serve and condition Griffiths's scenarios, which utilize this up-close focus in their development of the personal aspect of their personal-political dialectics. As well as the limited site of the drama which is conducive to a small cast and contained dramatic locations, Griffiths also exploits the camera's closeness to the actors, capturing intense exchanges in medium shots and close-ups and exploiting the sense that 'nearness to the actor's face was analogous to nearness to thought' ${ }^{38}$

Griffiths dramatizes the very processes by which political characters repress and overrule personal concerns. Absolute Beginners foregrounds the continual acts of mental and 
physical discipline and self-repression that are necessary for Lenin to retain the discipline and rigour that he demands of himself. When we first see him in the play, he is performing press-ups; later, he refuses to allow his wife Krupskaya to call the doctor when he has a painful bout of shingles, as he has political duties to attend to. In a further domestic scene when Krupskaya offers to sing to him he refuses, saying, 'No more music. It's too . . . moving. It softens'; and this is followed by a shot of him writing at his desk at 3.00 a.m. while Krupskaya sleeps. ${ }^{39}$

\section{Exploring Contradictions in Close-ups}

Tight shots often increase the capacity of performance - and of facial expressions in particular - to explore and expose contradictions between political proclamations and personal sentiments. For example, Lenin's troubled personal conscience is expressed during his nightmarish delirium while ill, revealing personal doubts that he would never consciously express. A close-up of his face, eyes closed and sweat dripping off him as he tosses and turns, captures his torment, which the dialogue explicitly links to his political differences with Julius Martov over the creation of a vanguard party: 'It's simple. See. I am the Party. Right. Party Organ . . . unh? ... unh? Central Committee ... Right? Central Organ, Central Committee ... See ... I am the Party . . No, I . . Mmm? Mmm? . . Julius, you're not listening. Martov!!"40

In All Good Men, director Michael LindsayHogg used expressionistic camerawork to represent the burden of confused and painful memories leading up to Edward Waite's mild heart attack. The snippets of various historic Labour speeches, and voice-over of Waite's ex-wife Ann alluding to an affair and to her dominance in their sexual relationship, are accompanied by a pattern of quick, repetitive camera zooms from long shots to medium close-ups, and from medium closeups to close-ups of Waite as he sits alone at his dining table. The repeated camera movements towards him generate a sense both of the outside world and of us, the spectators, entering into his head, reinforcing the notion of a direct relationship between external and internal realms of experience, as well as the audience accessing his thoughts.

Another interesting application of the close-up occurs when the play opens on a close-up of Waite speaking, as Griffiths's script specifies:

(Quietly, as though to a question.) Twenty-six was the turning point, I suppose. ... You couldn't work in the pit as I did and not be affected. (Pause.) Politically, I mean. ${ }^{41}$

As soon as he finishes this line, the shot changes to a high-angle establishing shot showing him sitting by himself in a conservatory referring to a sheaf of papers, implying that what we have just heard is being rehearsed from a script, while around him a television crew are setting up their production equipment.

By shooting the opening scene in this tight close-up, Lindsay-Hogg was exploiting the intimate connotations of the close-up shot before demonstrating that a false confidence is being constructed, using the closeness of the shot to command our attention on Waite and suggest his sincerity, while concealing the activity that is occurring around him and the fact that he is rehearsing his lines.

This strategy connects with wider themes in the play regarding how political figures and historical events are constructed by the media, the illusion of the unmediated image and spontaneous speech, and politicians' selective cultivation of their public identity.

While the television studio's 'intimacy' is useful for exploring the subject's internal contradictions, in other respects its lack of social extension hinders the full realization of characters in political drama. Such an effect is evident in Gramsci's two speeches to the striking Fiat workers in the television version of Occupations. In the theatre production of the play, Gramsci addresses the audience directly, placing them in the position of the workers. In the television version, aside from the unavoidable lack of a live audience there are further representational problems arising from camera framing and mise-en-scène that affect the mode of address. 
Both speech scenes are shot in black and white, the shift from colour (used in the rest of the drama) instantly differentiating them, and having connotations of documentary film footage. His first speech, in which he encourages the striking workers and contemplates their tactics, is framed in a low-angle medium close-up, with three workers positioned in shot behind him, and the spatial capacity of the barn location where it was shot is not visually evident, only alluded to through the echo of the room's acoustic (which also suggests that it is empty).

The tight focus of the shot (presumably at least partly due to possibilities limited by budget constraints) denies us any real sense of Gramsci as a public figure capable of inspiring the masses, and renders his address in such a way that it becomes more like an intimate soliloquy, revealing his own thoughts and feelings, than an inspirational address to a mass rally, demonstrating the political impact of his actions in the exterior world. Although Jack Shepherd gave a passionate and convincing speech, his performance, matching the scale of the visual language, does not seem to be a fully public mode of delivery.

The second speech scene, in which Gramsci announces the results of the referendum in which a deal is struck with the employers, is shot even more tightly, with no workers fully in shot (just the arm of one figure visible). Gramsci's disappointment is expressed in Jack Shepherd's performance and the slightly high angle which conveys a sense of his diminished confidence.

\section{Television Drama and Distance}

Several critics have remarked that television studio drama allows the spectator critical distance from the subject, and this has interesting potential applications with regard to the positioning of the spectator and the presentation of arguments in Griffiths's works. The sense of audience participation which is achieved in Up the Junction through features 'made available by location-filming (including street-sound, natural daylight, traffic, a populated world, movement)', ${ }^{42}$ and shoot- ing strategies such as 'a jerky and permanently shifting system of close-up shots which effectively corresponded with the movement of the observer's eye', ${ }^{43}$ is contrasted by MacMurraugh-Kavanagh and Lacey with the presentational mode of the studio, which accords the onlooker more critical distance from the subject by not immersing us in the world represented.

Jason Jacobs also explores the different processes by which meaning is created through filmed and television recording methods of capturing actors' performances. He quotes the actress Sybil Thorndike, who discusses how the acting technique required by television differs from that of theatre and film:

Television is going to give us an entirely new kind of acting. Different from stage acting because the nearness of the camera makes it more intimate. But even more different from film acting because the acting is continuous and the emotional pattern of the character is decided by the actor as he acts and not by the director on the floor or by the cutter in the cutting room. ${ }^{44}$

Jacobs also quotes Grace Wyndham Goldie's remark that Thorndike's 'face became a window through which she let us see into [her character] Widow Cagle's mind', suggesting that the centrality of the actor's performance places the spectator in a different relationship than is achieved in films:

Being 'let into' Widow Cagle's mind is not the same as thinking and feeling like Widow Cagle: instead of cinematic identification (seduction) here, this account suggests something more like close, intimate observation ... It is as if Thorndike does the work of identification for us ... deciding on the 'emotional pattern', and then showing it to the attentive, monitoring, television cameras. ${ }^{45}$

However, the spectator's position as 'observer' is not just determined by the actor's performance but also by the script and shooting strategies which determine how she is positioned. In the aforementioned accounts there is the implicit suggestion that film 'sutures' the viewer in more than television cameras do, putting the viewer in an identifying rather than observing position. But this is not always 
the case, and it would be misleading to draw a convenient technologically essentialist distinction between the shooting patterns adopted in each medium, as many film and television dramas use similar strategies.

In the Griffiths television texts discussed here, it is the script rather than the camera which seems to condition the 'presentational' rather than identifying mode, and this seems to be true of much 'theatrical' dialogue which asks to be presented rather than inviting us to occupy a particular perspective. In All Good Men, Absolute Beginners, and Occupations, shot/reverse-shot patterns and two-shots are most frequently adopted for the rhetorical dialogue exchanges, and close-ups are used in a variety of ways, but primarily to encourage us to understand their subjective states, and heighten moments of tension. These strategies are also shared by conventional or 'classical' film-makers, and it appears that it is not so much the camera that determines our relationship to characters as the fact that the writing favours the overall scenario over the individual, changing the parameters of our identification.

Griffiths's writing often presents two characters in opposition without an obvious preference for one character's point of view, and this balancing of arguments influences the fact that the audience is not 'seduced' (to use Jacobs's term) into identification. For example, although we are aligned with Kabak and Lenin more than with Gramsci and Martov as the personal lives of the latter are not represented, the plays encourage us to see the limitations and contradictions in all of the characters' political and moral perspectives (revealed through key speeches in the case of Gramsci and Martov).

John Bull has argued that television allows Griffiths to present 'a more pressing version of the dialectic', due to its ability 'to present a multiplicity of viewpoints'. ${ }^{46}$ In contrast to the sense of critical and experiential distance that some critics have stressed, Bull says that in Griffiths's televised works the audience is 'able to become involved to some extent with the experience and analysis of a number of differing characters', instead of 'looking in on the total event' as in the theatre. ${ }^{47}$
Indeed, the predominant recurrent use of a 'classical' shot/reverse-shot strategy over the static frontal mode associated with the theatre audience member, suggests that the level of visual audience interpolation is greater in television studio plays than some critics suggest, and that any distance is built into the plays' scenarios rather than being created through a theatrical presentation of the material.

This suggests that Griffiths's television plays invite a degree of emotional and psychological engagement (relating to the 'humanist' dimension of the drama) while at the same time refusing the spectator any easy object of identification as well as detracting from the personal narrative with broader socio-political and historical issues (relating to a 'structural' dimension). Griffiths has made it clear that the lack of resolution in his plays and the presentation of opposing viewpoints is a strategy that is intended to galvanize the audience into considering the issues for themselves:

I'll probably never complete a play in the formal sense. It has to be open at the end: people have to make choices, because if you're not making choices, you're not actually living. ${ }^{48}$

This quote is reminiscent of the Brechtian notion that the audience must be aroused to make interpretive decisions and, indeed, of the underlying respect for the intelligence of the audience that this implies.

\section{Conclusions}

The television studio is a site that enabled the prioritizing of ideas and concepts over socially extended, action-based narratives, and this is well adapted to Griffiths's concern with socialist theoretical problematics, his exploration of 'ruling ideas' Marxism via radical intellectuals, and his use of discursive form. The relation between ideas and experience is an issue that is both refracted through the form of Griffiths's highly theoretical dialogues and is often the very issue being addressed in his narratives, pointing towards the disparity between the high 
theoretical development of the New Left and the lack of collective engagement in militant action during the 1970s, and the question of how useful a theoretical critique of strategy is while it remains detached from action.

As an obviously constructed form free from certain constraints of verisimilitude, the studio also allows greater socio-political analysis than a socially extended naturalistic mode. The 'realism' of Griffiths's scenarios is constantly under negotiation as tensions between political debate and the interpersonal narratives that contain them are evident and the competing imperatives of intervention and reflection are in flux. The dichotomy of socio-political analysis and the representation of individual experience is kept active by Griffiths in his explorations of the socialist subject; the intimacy of the television studio mode enables a closer focus on the personal, felt dimension that was an important consideration for the New Left both in terms of understanding changes in class consciousness and in reassessing the category of the individual in Marxism in the post-Stalin era.

Contradictions between political commitments and personal feelings are emphasized and there is a continual dialectical movement between structural and humanist levels in both dialogic form and content. While critics have pointed to the critical distance established within much studio drama, filming techniques that invite our alignment and empathy with different characters are frequently used, but Griffiths's recurrent strategy of presenting the contradictory flaws within every character's approach in his strongly dialectical dramas means that there is no obvious solution to the dilemmas presented, and his texts remain open.

\section{Notes and References}

1. Mike Poole and John Wyver, Powerplays: Trevor Griffiths in Television (London: BFI Publishing, 1984), p. 7.

2. This information is from an interview with Griffiths conducted on 8 May 1979 by Edward Braun. In Braun's chapter on Griffiths in George W. Brandt, ed., British Television Drama (Cambridge: Cambridge University Press, 1981), p. 56, Braun summarizes that Griffiths told him, 'he had already reached the point where ... he saw writing for the stage largely as the necessary means of sustaining a reputation which would enhance his bargaining power when dealing with television'.

3. In an interview for Plays and Players (April 1972), p. 83, Griffiths states, 'It's in television that I think as a political writer, I want to be, because very large numbers of people, who are not accessible in any other way, are accessible in television.' Cited in Janet Wolff, Steve Ryan, Jim McGuigan, and Derek McKiernan, 'Problems of Radical Drama: the Plays and Productions of Trevor Griffiths', in F. Barker, J. Coombes, P. Hulme, D. Musselwhite and R. Osborne, ed., Literature, Society, and the Sociology of Literature: Proceedings of the Conference held at the University of Essex, July 1976, p. 133-53.

4. Trevor Griffiths, Preface to Through the Night and Such Impossibilities (London: Faber, 1977), p. 7.

5. This canon of drama includes works such as $U p$ the Junction (Wednesday Play, BBC1, 3 November 1965), Cathy Come Home (Wednesday Play, BBC1, 16 November 1966) and Edna the Inebriate Woman (Play for Today, BBC 1 , 21 October 1971).

6. In 'Who Framed Theatre? The "Moment of Change" in British TV Drama', New Theatre Quarterly, XV, No. 1 (Feb. 1999), p. 58-74, MacMurraugh-Kavanagh and Lacey detail how audiences grew increasingly dissatisfied with the 'artificiality' of studio drama after the advent of the Loach-Garnett filmed mode.

7. Interview on The Late Show, BBC2, January $1992-$ the day before The Gulf Between Us opened at West Yorkshire Playhouse.

8. Trevor Griffiths, 'Countering Consent: an Interview with Jon Wyver', in F. Pike, ed., Ah! Mischief: the Writer and Television (London: Faber, 1982), p. 38.

9. Of the film scripts that he wrote in the 1980 on only Reds (1981) and Fatherland (1986) were produced.

10. MacMurraugh-Kavanagh and Lacey, p. 72.

11. Raymond Williams, Keywords: a Vocabulary of Culture and Society (London: Fontana, 1983), p. 117.

12. Loach interview with Jeremy Isaacs on Face to Face, BBC2, 19 September 1994.

13. In Griffiths's televised dramas during the 1970 s Jack Shepherd was cast as William Waite in All Good Men, Antonio Gramsci in Occupations, Dr Pearce in Through the Night (Play for Today, BBC1, 2 December 1975), and in the title role in Bill Brand (Thames TV, 7 June-16 August 1976).

14. Andrew Milner, Class (London: Sage, 1999), p. 28.

15. Another Griffiths text which explores the potential of political parties is the eleven-part series Bill Brand (Thames TV, 7 June-16 August 1976), about a young Trotskyist's experiences as a Labour MP.

16. Pleasence acted with the Birmingham Rep and Bristol's Old Vic Company, as well as on Broadway alongside Laurence Olivier, and on the London fringe before turning his attention to a screen career in the mid1950s. He took many roles in Armchair Theatre, as well as important dramas such as Nineteen Eighty-Four (1956) and the popular series The Adventures of Robin Hood (ITV, 1955-60)

17. Cited in Michael Patterson, Strategies of Political Theatre: Post-War British Playwrights (Cambridge: Cambridge University Press, 2003), p. 67.

18. MacMurraugh-Kavanagh and Lacey, p. 67-8. The line quoted was a slogan of the May 1968 Paris uprisings.

19. Ibid., p. 67.

20. Trevor Griffiths, Collected Plays for Television (London: Faber and Faber, 1988), p. 68-9. 
21. Ibid., p. 67

22. Ibid., p. 41.

23. MacMurraugh-Kavanagh and Lacey, p. 70.

24. Ibid., p. 72.

25. Jacob Leigh discusses the difficulties of communicating certain necessary political information while retaining the sense that characters might 'walk off by themselves', beyond the camera frame, in The Films of Ken Loach: Art in the Service of People (London: Wallflower Press, 2002) p. 12-13.

26. Trevor Griffiths (1982), p. 39.

27. Trevor Griffiths (1988), p. 50.

28. Ibid., p. 56-7.

29. Ibid., p. 53 .

30. Eugene Lunn, Marxism and Modernism: an Historical Study of Lukács, Brecht, Benjamin, and Adorno (London: Verso, 1985), p. 87.

31. Trevor Griffiths (1982), p. 39

32. Dorrian Lambley, 'In Search of a Radical Discourse for Theatre', New Theatre Quarterly, VIII, No. 29 (Feb. 1992), p. 42.

33. Michael Kenny, The First New Left: British Intellectuals after Stalin (London: Lawrence and Wishart, 1995) p. 70-1.

34. Paul Madden, interview in Complete Programme Notes for a Season of British Television Drama 1959-1973, held at the National Film Theatre, 11-24 October 1976 (London: British Film Institute, 1976), cited in Philip
Purser, 'Dennis Potter', chapter in George Brandt, ed., British Television Drama (Cambridge: Cambridge University Press, 1981).

35. In The Intimate Screen: Early British Television Drama (Oxford: Oxford University Press, 2000), p. 123, Jason Jacobs discusses in depth the issues surrounding television's associations with intimacy, and points out that the "intimate" aspects of television drama - closeup acting, its interpretation and observation by the producer, and the close-up as the primary style of visualization - were really expressions of the limited critical thinking about television, rather than the actual limits of the medium'.
36. Ibid., p. 122.
37. Ibid., p. 129.
38. Ibid., p. 122.
39. Trevor Griffiths (1988), p. 98
40. Ibid., p. 103.
41. Ibid., p. 39.
42. MacMurraugh-Kavanagh and Lacey, p. 64
43. Ibid., p. 65.
44. Ibid., p. 118.
45. Ibid.
46. John Bull, New British Political Dramatists (London: Macmillan, 1984), p. 138
47. Ibid., p. 138-9.
48. Times Educational Supplement, 25 June 1976, cited in John Bull, New British Political Dramatists. 